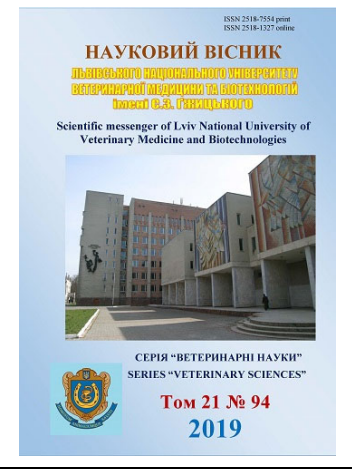

\author{
Науковий вісник Дьвівського національного університету \\ ветеринарної медицини та біотехнологій імені С.З. Гжицького. \\ Серія: Ветеринарні науки \\ Scientific Messenger of Lviv National University \\ of Veterinary Medicine and Biotechnologies. \\ Series: Veterinary sciences
}

UDC 619.615

\title{
The degree of cumulation of the "Bendamin" drug in the body of white rats
}

\author{
I.S. Varkholiak, B.V. Gutyj
}

Stepan Gzhytskyi National University of Veterinary Medicine and Biotechnologies Lviv, Ukraine

Article info

Received 09.04.2019 Received in revised form 10.05.2019

Accepted 13.05.2019

Stepan Gzhytskyi National University of Veterinary Medicine and Biotechnologies Lviv, Pekarska Str., 50, Lviv, 79010, Ukraine. Tel.: +38-096-486-26-85 E-mail: irynkavet@ukr.net
Varkholiak, I.S., \& Gutyj, B.V. (2019). The degree of cumulation of the "Bendamin" drug in the body of white rats. Scientific Messenger of Lviv National University of Veterinary Medicine and Biotechnologies. Series: Veterinary sciences, 21(94), 82-85. doi: 10.32718/nvlvet9415

Repeated introduction into the body of an animal of a medicinal substance can lead to its accumulation in the tissues of the body. Therefore, knowledge of the cumulative properties of substances or conditions that may lead to cumulations, are especially important for understanding the pathogenesis of intoxication, because this phenomenon often lies at the basis of acute and chronic poisoning. The purpose of the work was to study the degree of cumulation of the "Bendamin" preparation in the body of white rats. The properties of the cumulative drug were studied in 12 white rats weighing 150-160 g. Rats were divided into 2 groups: control and experimental. To determine the cumulative properties of Bendamin, it was administered to laboratory animals starting at a dose of $0.1 \mathrm{DL}_{50}$, with a sequential increase in the dose of 1.5 times every 4 days. It was found that the cumulative coefficient of Bendamin was 8.31 units, indicating that the drug does not exhibit cumulative effects. In determining the mass coefficients of the internal organs in the animals of the experimental group, the tendency to increase the weight and liver mass coefficients was determined, respectively, by 5.2 and $5.1 \%$. The weight ratio of the heart of the animals of the experimental group increased by $5.7 \%$ relative to the control group. After studying the morphological parameters of blood of rats at 24 days of the experiment for studying the cumulative properties of the "Bendamin" drug, an increase in the number of erythrocytes to $6.13 \pm 0.27 \mathrm{~T} / \mathrm{L}$, white blood cells to $8.42 \pm 0.54 \mathrm{G} / \mathrm{L}$ and hemoglobin up to $132.4 \pm 2.44 \mathrm{~g} / \mathrm{l}$. In the analysis of leukocyte profile in rats, there was a decrease in the number of eosinophils and monocytes, respectively, at 1.1 and $1.3 \%$ relative to the control group. The number of lymphocytes in the blood of the experimental group of rats increased by $1.5 \%$, while neutrophils by $0.9 \%$ compared to the control. When studying the level of total protein, its small increase was determined by $5.2 \%$. The activity of aminotransferases in the blood serum of experimental rats on the 24th day of the experiment for the study of cumulative properties of the drug also increased by 13 and $8 \%$ relative to the control group. Also, creatinine and total bilirubin levels in their rat blood were decreased by 3.1 and $8.8 \%$, respectively.

Key words: pharmacology, toxicology, toxicity, preparation “Bendamin”, white rats, cumulation.

\section{Ступінь кумуляції препарату “Бендамін” в організмі білих щурів}

\author{
І.С. Вархоляк, Б.В. Гутий
}

Львівський національний університет ветеринарної медицини та біотехнологій імені С.3. Гжиџького, м. Львів, Україна

Багаторазове введення в організм тварин лікарської речовини може призвести до нагромадження ї̈ у тканинах організму, тому знання кумулятивних властивостей речовин або умов, які можуть призвести до кумуляції, особливо важливі для розуміння патогенезу інтоксикації, бо ие явище часто лежить в основі гострих і хронічних отруєнь. Метою роботи було вивчити ступінь кумуляиії препарату “Бендамін” в організмі білих шурів. Властивості препарату щзодо кумуляції вивчали на 12 білих щурах масою 150-160 г. Щури були поділені на 2 групи: контрольну та дослідну. Для визначення кумулятивних властивостей препарату “Бендамін”, його вводили лабораторних тваринам починаючи з дози 0,1 DL50, з послідовним збільшенням дози у 1,5 рази через кожні 4 доби. Встановлено, щуо коефіцієнт кумуляиї препарату “Бендамін” становив 8,31 одиниці, щзо вказувє на те, щзо препарат не 
проявляє кумулятивної дії. При визначенні масових коефіцієнтів внутрішніх органів у тварин дослідної групи встановлено тенденцію до збільшення коефіцієнтів маси печінки та селезінки, відповідно, на 5,2 та 5,1\%. Масовий коефіцієнт серия тварин дослідної групи зріс на 5,7\% відносно контрольної групи. Після дослідження морфологічних показників крові шурів на 24 добу досліду за вивчення кумулятивних властивостей препарату “Бендамін”, встановлено зростання кількості еритроцитів до 6,13 \pm 0,27 Т/л, лейкоиитів до 8,42 \pm 0,54 Г/л та гемоглобіну до 132,4 \pm 2,44 г/л. При аналізі лейкоцитарного профілю у щурів, встановлено зниження кількості еозинофілів та моноцитів відповідно на 1,1 та 1,3\% відносно показників контрольної групи. Кількість лімфоцитів у крові дослідної групи щурів зросла на 1,5\%, тоді як нейтрофілів на 0,9\% порівняно з контролем. При дослідженні рівня загального протеїну, встановлено його незначне збільшення на 5,2\%. Активність амінотрансфераз у сироватці крові шурів дослідної групи на 24 добу досліду за вивчення кумулятивних властивостей препарату також зростала на 13 і 8\% відносно контрольної групи. Також встановлено зниження рівня креатиніну та загального білірубіну у їх крові щурів відповідно на 3,1 i 8,8\%.

Ключові слова: фармакологія, токсикологія, токсичність, препарат “Бендамін”, білі щурі, куміляџія.

\section{Вступ}

Патології серцево-судинної системи займають провідне місце серед хвороб незаразної етіології і є основною причиною смертності. Статистичні дані вказують про те, що хвороби серця виявляють у 5$10 \%$ пацієнтів, що поступили на прийом до лікаря. Встановлено ряд факторів ризику виникнення патології серцево-судинної системи, зокрема породну схильність: собаки дрібних і середніх порід схильні до розвитку набутих хвороб клапанів (хронічна хвороба клапанів, ендокардіоз), в той час як для собак великих порід характерний розвиток дилятаційної кардіоміопатії (ДКМ) і хвороб перикарду (Undhad et al., 2012; Varkholiak, 2016; Zhulikova, 2016).

Зважаючи на аналіз даних вітчизняних і зарубіжних дослідників розробка зручного у застосуванні і безпечного комплексного кардіологічного препарату, використання якого дозволить підвищити ефективність лікування тварин і широкого спектру серцевосудинних патологій $\epsilon$ на часі і становить актуальність проведення досліджень для ветеринарної медицини.

Відповідно до постанови Департаменту ветеринарної медицини “Токсикологічний контроль нових засобів захисту тварин”, затверджених Головним управлінням ветеринарної медицини Мінсільгосппроду України від 16 грудня 1996 р., кожний новий препарат, що рекомендується для лікування тварин, повинен відповідати таким вимогам (Todoriuk et al., 2018):

- новий препарат, у порівнянні 3 препаратоманалогом, повинен проявляти вищу терапевтичну ефективність;

- він повинен бути не токсичним для тварин, яким його застосовують;

- препарат або його метаболіти не повинні впливати на санітарну якість та поживну цінність тваринницької продукції;

- у процесі виробництва та застосування препарат не повинен спричиняти шкоди для довкілля.

Метою роботи було вивчити ступінь кумуляції препарату “Бендамін” в організмі білих щурів.

\section{Матеріал і методи досліджень}

Експериментальні дослідження проведені у відповідності до вимог лікарсько-біологічного експерименту з підбору аналогів, постановці контролю, дотриманню однакових умов годівлі та утримання під час проведення досліду та обліку результатів (Kotsiumbas et al., 2006; Gutyj et al., 2016; 2017; 2018).

Властивості препарату щодо кумуляції вивчали на 12 білих щурах масою 150-160 г. Щури були поділені на 2 групи: контрольну і дослідну. Для визначення ступеня кумуляції препарату використали метод К.С. Ліма та співавторів (1961) (Malanin et al., 1988).

Для визначення кумулятивних властивостей препарату “Бендамін”, його вводили лабораторних тваринам починаючи 3 дози $0,1 \mathrm{DL}_{50}, 3$ послідовним збільшенням дози у 1,5 рази через кожні 4 доби. Під час досліду враховували загальний стан і загибель щурів.

Залежно від дії препарату у дозі, вираховували коефіцієнт кумуляції за формулою, запропонованою Ю.С. Каганом і В.В. Станкевичем (Shtabskij \& Kagan, 1974):

$$
\mathrm{K}_{\text {кум }}=\mathrm{DL}_{50 \mathrm{n}} / \mathrm{DL}_{501} \text {, }
$$

де $\mathrm{K}_{\text {кум }}$ - коефіцієнт кумуляції, DL 50 n DL $_{501}$ - ceредні смертельні дози за багаторазового та одноразового введення відповідно.

Для виявлення впливу препарату у вищевказаних дозах на організм, в кінці досліду щодо кумуляції на наступну добу після останнього введення препарату “Бендамін”, тварин із кожної групи зважували, декапітували за умов легкого ефірного наркозу та відбирали від них зразки крові для проведення гематологічних і біохімічних досліджень (Vlizlo et al., 2012). Після патологоанатомічного розтину від тварин відбирали внутрішні органи, зважували та вираховували коефіцієнти їх маси, порівняно 3 контрольною групою.

\section{Результати та їх обговорення}

За умов дослідження властивостей препарату “Бендамін” в дозах щодо кумуляції загибелі дослідних тварин протягом досліду не виявлено.

Сумарна середня введена доза $\left(\mathrm{DL}_{50 n}\right)$ на одного щура протягом усього експерименту становила: $\mathrm{DL}_{50 \mathrm{n}}=(500 \cdot 4)+(750 \cdot 4)+(1125 \cdot 4)+(1687,5 \cdot 4)+$ $(2531,25 \cdot 4)+(3796,875 \cdot 4)=41562,5$ мг/кг.

$$
\mathrm{DL}_{50 \mathrm{n}}=2000+3000+4500+6750+10125
$$$$
+15187,5=41562,5 \mathrm{мг} / \mathrm{кг} \text {. }
$$

Згідно з формулою, коефіцієнт кумуляції $\left(\mathrm{K}_{\text {кум }}\right)$ становить:

$$
\mathrm{K}_{\text {кум }}=41562,5: 5000=8,31 \text { одиниць }
$$

Отже, коефіцієнт кумуляції препарату "Бендамін" становив 8,31 одиниці, що вказувало на те, що 
препарат не проявляє кумулятивної дії.

Для виявлення здатності препарату “Бендамін” накопичуватися в органах та тканинах білих щурів проводили визначення їх масових коефіцієнтів внутрішніх органів. Результати досліджень наведено у таблиці 1. Як видно 3 даних, наведених у таблиці 1 , при визначенні масових коефіцієнтів внутрішніх органів у тварин дослідної групи встановлено тенденцію до збільшення коефіцієнтів маси печінки та селезінки, відповідно, на 5,2 та 5,1\%. Масовий коефіцієнт серця тварин дослідної групи зріс на 5,7\% відносно контрольної групи.

Встановлено, що у щурів дослідної групи масовий коефіцієнт нирок незначно знизився відносно контролю, де відповідно масовий коефіцієнт правої нирки становив $3,1 \pm 0,14$, лівої нирки $-3,5 \pm 0,11$, тоді як у контролі дані показники становили $3,3 \pm 0,13$ i $3,7 \pm 0,12$.

\section{Таблиця 1}

Коефіцієнти маси внутрішніх органів білих щурів 3 вивчення кумулятивних властивостей препарату “Бендамін” ( $\mathrm{M} \pm \mathrm{m}, \mathrm{n}=6)$

\begin{tabular}{lrr}
\hline \multicolumn{1}{c}{ Внутрішні органи } & Контроль & \multicolumn{1}{c}{ Дослід } \\
\hline Печінка & $34,6 \pm 1,10$ & $36,4 \pm 2,15$ \\
Серце & $3,5 \pm 0,16$ & $3,7 \pm 0,29$ \\
Селезінка & $3,9 \pm 0,20$ & $4,1 \pm 0,13$ \\
Легені & $8,3 \pm 0,31$ & $8,7 \pm 0,45$ \\
Нирка права & $3,3 \pm 0,13$ & $3,1 \pm 0,14$ \\
Нирка ліва & $3,7 \pm 0,12$ & $3,5 \pm 0,11$ \\
Тимус & $2,25 \pm 0,23$ & $2,42 \pm 0,7$ \\
\hline
\end{tabular}

Величина коефіцієнтів маси легень та тимусу на період досліджень коливалася у межах 8,7 $\pm 0,45$ i $2,42 \pm 0,7$ проти контрольної групи 8,3 $\pm 0,31$ i 2,25 \pm 0,23 .

Після дослідження морфологічних показників крові щурів на 24 добу досліду за вивчення кумулятивних властивостей препарату "Бендамін”, встановлено зростання кількості еритроцитів до 6,13 \pm 0,27 Т/л, лейкоцитів до $8,42 \pm 0,54$ Г/л та гемоглобіну до $132,4 \pm 2,44$ г/л проти відповідних контрольних значень: $5,81 \pm 0,25$ Т/л, 8,34 $\pm 2,76$ Г/л, $126,1 \pm 2,11$ г/л (табл. 2).

\section{Таблиця 2}

Морфологічні показники крові щурів на 24 добу досліду за вивчення кумулятивних властивостей препарату “Бендамін” ( $\mathrm{M} \pm \mathrm{m}, \mathrm{n}=6)$

\begin{tabular}{ccc}
\hline \multirow{2}{*}{ Показники } & \multicolumn{2}{c}{ Групи тварин } \\
\cline { 2 - 3 } & Контрольна & Дослідна \\
\hline Гемоглобін, г/л & $126,1 \pm 2,11$ & $132,4 \pm 2,44$ \\
Еритроцити, Т/л & $5,81 \pm 0,25$ & $6,13 \pm 0,27$ \\
Лейкоцити, Г/л & $8,34 \pm 2,76$ & $8,42 \pm 0,54$ \\
Еозинофіли, \% & $2,14 \pm 0,14$ & $1,04 \pm 0,31^{*}$ \\
Нейтрофіли, \% & $25,2 \pm 1,61$ & $26,1 \pm 1,40$ \\
Лімфоцити, \% & $69,6 \pm 1,95$ & $71,1 \pm 1,48$ \\
Моноцити, \% & $3,06 \pm 0,32$ & $1,76 \pm 0,23^{*}$ \\
\hline Примітка: ступінь вірогідності $-* \mathrm{P}<0,05$
\end{tabular}

Примітка: ступінь вірогідності - * $\mathrm{P}<0,05$
При аналізі лейкоцитарного профілю у щурів на 24 добу досліду за вивчення кумулятивних властивостей препарату “Бендамін”, встановлено зниження кількості еозинофілів та моноцитів відповідно на 1,1 та 1,3\% відносно показників контрольної групи. Кількість лімфоцитів у крові дослідної групи щурів зросла на $1,5 \%$, тоді як нейтрофілів на $0,9 \%$ порівняно 3 контролем.

Встановлено, що тривале введення препарату “Бендамін” у зростаючих дозах впливало на деякі біохімічні показники дослідних тварин (табл. 3). При дослідженні рівня загального протеїну, встановлено його незначне збільшення у крові дослідної групи щурів на 24 добу досліду на 5,2\% порівняно 3 контрольною групою. Активність амінотрансфераз у сироватці крові щурів дослідної групи на 24 добу досліду за вивчення кумулятивних властивостей препарату також зростала на 13 і 8\% відносно контрольної групи. Активність лужної фосфатази у сироватці крові дослідних щурів зросла до 162,6 $\pm 31,2$ Од/л, тоді як у контрольної групи щурів даний показник був дещо нижчим і відповідно становив 158,5 \pm 25,4 Од/л.

Поряд із зростання ензимів у сироватці крові щурів дослідної групи, також встановлено зниження рівня креатиніну та загального білірубіну у їх крові відповідно на 3,1 і 8,8\%.

\section{Таблиця 3}

Біохімічні показники крові щурів на 24 добу досліду за вивчення кумулятивних властивостей препарату “Бендамін” ( $\mathrm{M} \pm \mathrm{m}, \mathrm{n}=6)$

\begin{tabular}{|c|c|c|}
\hline \multirow{2}{*}{ Показники } & \multicolumn{2}{|c|}{ Групи тварин } \\
\hline & Контрольна & Дослідна \\
\hline Протеїн загальний, г/л & $68,45 \pm 1,77$ & $72,05 \pm 2,32$ \\
\hline АлАТ, Од/л & $63,2 \pm 2,46$ & $71,4 \pm 2,37 *$ \\
\hline АсАТ, Од/л & $161,1 \pm 3,66$ & $174,3 \pm 4,58 *$ \\
\hline ЛФ, Од/л & $158,5 \pm 25,4$ & $162,6 \pm 31,2$ \\
\hline Креатинін, мкмоль/л & $77,2 \pm 1,19$ & $74,8 \pm 1,83$ \\
\hline Сечовина, ммоль/л & $6,58 \pm 0,41$ & $6,64 \pm 0,25$ \\
\hline $\begin{array}{l}\text { Білірубін } \\
\text { мкмоль/л }\end{array}$ & $3,76 \pm 0,52$ & $3,43 \pm 0,40$ \\
\hline
\end{tabular}

Концентрація сечовини у крові щурів на 24 добу досліду за вивчення кумулятивних властивостей препарату "Бендамін" коливалася у межах 6,64 0,25 ммоль/л, проти контрольних величин $6,58 \pm$ 0,41 ммоль/л.

\section{Висновки}

Препарат “Бендамін” не володіє кумулятивною активністю, коефіцієнт кумуляції становив 8,31 одиниці. За цих умов, застосування препарату призводило до стимуляції гемопоезу та посилення протеїнсинтезувальної функції печінки. 


\section{References}

Gutyj, B., Grymak, Y., Hunchak, V., Mysak, A., Nazaruk, N., Brezvyn, O., Hariv, I., Shcherbatyy, A., Semeniv, B., Bushueva, I., Parchenko, V., \& Kaplaushenko, A. (2018). Preclinical searches of the preparation Thireomagnile. Ukrainian Journal of Ecology, 8(1), 688-695. doi: 10.15421/2018_267.

Gutyj, B., Khariv, I., Binkevych, V., Binkevych, O., Levkivska, N., Levkivskyj, D., \& Vavrysevich, Y. (2017). Research on acute and chronic toxity of the experimental drug Amprolinsyl. Regul. Mech. Biosyst., 8(1), 41-45. doi: 10.15421/021708.

Gutyj, B., Paska, M., Levkivska, N., Pelenyo, R., Nazaruk, N., \& Guta, Z. (2016). Study of acute and chronic toxicity of 'injectable mevesel' investigational drug. Biological Bulletin of Bogdan Chmelnitskiy Melitopol State Pedagogical University, 6(2), 174180. doi: 10.15421/201649.

Kotsiumbas, I.Ia., Malyk, O.H., \& Patereha, I.P. (2006). Doklinichni doslidzhennia veterynarnykh likarskykh zasobiv. L.: Triada plius (in Ukrainian).

Malanin, L.P., Morozov, A.P., \& Selivanova, A.S. (1988). Metodicheskie ukazanija po opredeleniju toksicheskih svojstv preparatov, primenjaemyh $\mathrm{v}$ veterinarii $\mathrm{i}$ zhivotnovodstve. Veterinarnye preparaty: Spravochnik. M.: Agropromizdat, 239-289 (in Russian).

Shtabskij, B.M., \& Kagan, Ju.S. (1974). K ocenke kumuljativnyh svojstv himicheskih veshhestv po indeksu i standartizovannomu kojefficientu kumuljacii. Gigiena i sanitarija, 3, 65-68 (in Russian).

Todoriuk, V.B., Hunchak, V.M., Gutyj, B.V., Gufriy, D.F., Hariv, I.I., Khomyk, R.I. , \& Vasiv, R.O. (2018). Preclinical research of the experimental preparation "Ferosel T". Ukrainian Journal of Veterinary and Agricultural Sciences, 1(1), 3-9. doi: 10.32718/ujvas1-1.01.

Undhad, V.V., Fefar, D.T., Jivan, B.M. Gupta, H., Ghodasara, D.J., Joshi, B.P., \& Prajapati, K.S. (2012). Cardiac troponin: an emerging cardiac biomarker in animal health. Vet. World, 5(8), 508-511. doi: 10.5455/vetworld.2012.508-511.

Varkholiak, I.S. (2016). The usage of medicines at the cardiovascular pathologies in dogs and cats. Scientific Messenger LNUVMBT named after S.Z. Gzhytskyj, 18, 3(71), 261-265. https://nvlvet.com.ua/index.php/ journal/article/view/974.

Vlizlo, V.V., Fedoruk, R.S., \& Raty`ch, I.B. (2012). Laboratorni metody' doslidzhen' u biologiyi, tvary`nny`cztvi ta vetery`narnij medy`cy`ni: dovidny`k. L`viv: Spolom (in Ukrainian).

Zhulikova, O.A. (2016). Monitoring rasprostranenija serdechno-sosudistyh zabolevanij sredi koshek i sobak v g. Blagoveshhensk amurskoj oblasti. Dal'nevostochnyj agrarnyj vestnik, 2(38), 49-56. https://cyberleninka.ru/article/n/monitoringrasprostraneniya-serdechno-sosudistyh-zabolevaniysredi-koshek-i-sobak-v-g-blagoveschensk-amurskoyoblasti (in Russian). 